Investigation of Some Biochemical Parameters in Sheep Naturally Infected with Cystic Echinococcosis

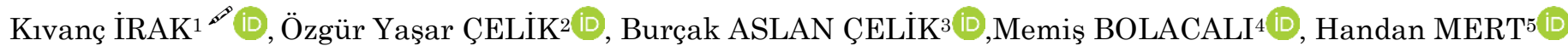 \\ Nihat MERT6 6 iD \\ ${ }^{1}$ Siirt Üniversitesi Veteriner Fakültesi, Biyokimya Anabilim Dalı, Siirt, ${ }^{2}$ Siirt Üniversitesi Veteriner Fakültesi, İ̧ Hastalıkları Anabilim Dalı, \\ Siirt, ${ }^{3}$ Siirt Üniversitesi Veteriner Fakültesi, Parazitoloji Anabilim Dalı, Siirt, ${ }^{4}$ Siirt Üniversitesi Veteriner Fakültesi, Zootekni Anabilim Dalı, \\ Siirt, 5, ${ }^{6}$ üzüncü Yıl Üniversitesi Veteriner Fakültesi, Biyokimya Anabilim Dalı, Van \\ ${ }^{1}$ https://orcid.org/0000-0001-9765-0330, ${ }^{2}$ https://orcid.org/0000-0001-6365-2688, ${ }^{3} \mathrm{https}: / /$ orcid.org/0000-0002-0130-970X \\ ${ }^{4}$ https://orcid.org/0000-0002-4196-2359, ${ }^{5}$ https://orcid.org/0000-0001-9827-7996, ${ }^{6}$ https://orcid.org/0000-0001-7185-3316 \\ $\bowtie$ : kivancirak@hotmail.com
}

\section{ABSTRACT}

This study was performed to reveal the changes in certain serum biochemical parameters in animals diagnosed with Cystic Echinococcosis. The material of the study consisted of 40 sheep aged 1-3, which were brought for slaughter from different animal farms of Siirt. Overall, 20 sheep which were determined to be healthy in physical examinations and had no pathological lesions in their internal organs were determined as the control group, while the remaining 20 sheep with cystic lesions in their lungs and livers which were protoscolex-positive formed the infected group. While no significant relevant difference between the $\mathrm{K}, \mathrm{Cl}, \mathrm{Ca}, \mathrm{Mg}$, GGT, ALT, ALB, TRIG and CHOL levels of health and infected animals ( $>0.05)$, statistically meaningful changes in $\mathrm{Na}(p<0.01)$, TBIL $(p<0.05)$, and TP and GLOB $(\mathrm{p}<0.001)$ levels and AST $(\mathrm{p}<0.001)$ activity were observed between the groups. As a result, it was determined that the changes in AST, total protein, globulin, and total bilirubin levels could be used as supportive laboratory analyzes in a determination of the prognosis of animals infected with Cystic Echinococcosus and of the physiopathologic alterations occurring in their livers.

\section{Research Article}

Article History
Received $\quad: 20.02 .2019$
Accepted $\quad: 23.05 .2019$

Keywords

Cyst hydatid

Blood parameters

Liver

\title{
Kist Hidatik ile Doğal Enfekte Koyunlarda Bazı Biyokimyasal Parametrelerin Araştırılması
}

\section{ÖZET}

Bu çalışmada, Kistik Ekinokokkozis tanısı konulan koyunlarda, bazı serum biyokimyasal parametrelerdeki değişimlerin araştırılması amaçlanmıştır. Çalışmanın materyalini Siirt ilindeki farklı işletmelerden kesime getirilen; 1-3 yaşlı 40 koyun oluşturdu. Yapılan organ muayenelerinde herhangi bir patolojik lezyon bulunmayan ve fiziki muayenede sağlıklı olduğu tespit edilen 20 adet koyun çalışmanın kontrol grubunu, karaciğer ve akciğerlerinde kistik yapılar parazitolojik olarak incelenerek protoskoleks yönünden pozitif olan 20 adet koyun çalışmanın enfekte grubunu oluşturdu. Sağlıklı ve enfekte gruplar arasinda $\mathrm{K}, \mathrm{Cl}, \mathrm{Ca}, \mathrm{Mg}, \mathrm{GGT}, \mathrm{ALT}, \mathrm{ALB}$, TRIG ve CHOL düzeyleri bakımından istatistiksel olarak anlamlı bir fark tespit edilmezken $(p>0.05), \mathrm{Na}(\mathrm{p}<0.01)$, TBIL $(\mathrm{p}<0.05)$, TP ve GLOB $(\mathrm{p}<0.001)$ seviyeleri ile AST $(\mathrm{p}<0.001)$ aktivitesi bakımından, gruplar arasındaki farkın anlamlı olduğu belirlendi. Sonuç olarak, AST, total protein, globülin ve total bilirubin düzeylerindeki değişimlerin, karaciğerde meydana gelen fizyopatolojik değişikliklerin tespit edilmesinde ve Kistik ekinokokkozis ile enfekte hayvanların prognozunun belirlenmesinde yardımcı laboratuvar analizleri olarak kullanılabileceği kanısına varılmıştır.

\section{Araştırma Makalesi}

Makale Tarihçesi

Geliş Tarihi : 20.03.2019

Kabul Tarihi : 23.05 .2019

\section{Anahtar Kelimeler \\ Kist hidatik \\ Kan parametreleri \\ Karaciğer}

To Cite : İrak K, Çelik ÖY, Aslan Çelik B, Bolacalı M, Mert H, Mert N 2019. Investigation of Some Biochemical Parameters in Sheep Naturally Infected with Cystic Echinococcosis. KSU J. Agric Nat 22(6): 948-952. DOI: 10.18016/ksutarimdoga.vi.529603 


\section{INTRODUCTION}

Cystic echinococcosis is a zoonotic disease caused by the larvae of the Echinococcus granulosus ( $E$. granulosus) infecting the intermediate hosts, and the disease represents a significant threat for human and animal health all around the globe (Yildiz and Gurcan, 2003; Hakverdi et al., 2008; Demir and Mor, 2011). The adults of $E$. granulosus live in the small intestines of the dogs and other canines that are the final hosts, while its larvae lives in various tissues and organs of humans and certain mammals, particularly in herbivores like sheep, goats, and cattle, which represent the intermediate hosts (Yildiz and Gurcan, 2003; Gicik et al., 2004; Gokcen et al., 2006; Hakverdi et al., 2008). The most important source of infection for humans and animals that are the intermediate hosts are the infected dogs. The vegetables, fruits, and drinking waters contaminated with the dog feces form the source of infection (Gokcen et al., 2006). The parasite is reported to be capable of settling into almost every organ, including lungs, kidneys, spleen, brain, and heart (Karaman et al., 2005).

Significant changes reportedly occur in blood parameters of animals exposed to the parasitic invasion (Mert et al., 2003; Ayaz et al., 2006; Sahin and Akgul, 2006; Tanritanir et al., 2009; Uslu et al., 2011). Parasitic infections seem to cause increased hepatic enzyme activity and decreased trace element levels by causing liver damage (Sahin and Akgul, 2006; Vengust et al., 2003). Some researchers report that investigating the hepatic enzyme activities and total bilirubin, protein, and albumin levels are helpful in the evaluation of the liver functions (Tennant and Center, 2008). Minerals, on the other hand, have an important role in maintaining normal physiological functions and protecting organisms against disease. These substances are found in the structure of cofactors that are necessary for enzymatic activity (Karagul, 2000).

Considering the relationship of the cystic echinococcosis with certain biochemical parameters, various studies were thus performed both in humans (Koltas et al., 2006; Ersayit et al., 2009; Kilic et al., 2010), sheep (Sagkan-Ozturk et al., 2015; Cinar et al., 2018; Irak et al., 2018) and cattle (Yarim et al., 2010, Heidarpour et al., 2013; Hanedan et al., 2015). The fact that clinical findings are not conclusive in cystic echinococcosis, and the parasitologic examinations being unable to provide specific results, makes the disease difficult to diagnose in intermediate hosts. The determination of blood parameters is further important as the rate of success in the treatment increases with early diagnosis of the disease (Kam, 2016).

The objective of this study, was to investigate the changes in certain serum biochemical parameters in sheep diagnosed with Cystic echinococcosis.

\section{MATERIALS and METHODS}

Study Area

Siirt province lays in the semi-arid climate region. The average highest and lowest temperatures range from $36.9{ }^{\circ} \mathrm{C}$ and $18.9{ }^{\circ} \mathrm{C}$ in summer and there are water shortages during the summer (Meteorology, 2018).

\section{Ethical Approval}

All applicable international, national, and/or institutional guidelines for the care and use of animals were followed.

\section{Animal Material}

Total of 40 sheep at the age of 1 to 3 years brought in for a slaughter from various establishments in the province of Siirt. The general health status of the sheep were examined physically and blood samples were collected. The organs of the animals were checked for cyst hydatid after the slaughter. 20 sheep which were found to be healthy in physical examinations and had no pathological lesions in their internal organs were determined as the control group, while the remaining 20 sheep with cystic lesions in their lungs and livers which were protoscolex-positive formed the test group. The blood samples collected into anticoagulant-free test tubes were kept in room temperature for 30 minutes and then centrifuged in $3000 \mathrm{rpm}$ for 10 minutes. The analyses of Sodium (Na), Potassium (K), Chloride (CI), Calcium (Ca), Magnesium (Mg), Gamma-Glutamyl Transferase (GGT) Alanine Aminotransferase (ALT), Aspartate Aminotransferase (AST), Total bilirubin (TBIL), Total protein (Tp), Albumin (Alb), Globulin (GLOB), Triglyceride (TRIG), Cholesterol (CHOL) were performed using an ADVIA 1800 brand autoanalyzer device.

\section{Statistical Analysis}

SPSS 16.0 Windows program (SPSS Inc., Chicago, IL) was used for statistical analysis of the data. Independent t-test was used when differences between groups were determined and the results were given as mean \pm SEM (Standard Error of Mean). P $<0.05$ was considered statistically significant.

\section{RESULTS and DISCUSSION}

The analysis results for certain biochemical parameters of the healthy animals in the control group and the animals in the test group diagnosed with Cystic echinococcosis were given in Table 1. No statistical difference was observed between the $\mathrm{K}, \mathrm{Cl}$, $\mathrm{Ca}, \mathrm{Mg}, \mathrm{GGT}$, ALT, ALB, TRIG, and CHOL levels between the groups $(p>0.05)$, while the difference between the groups in terms of $\mathrm{Na}(\mathrm{p}<0.01)$, TBIL $(\mathrm{p}<0.05)$, TP and GLOB $(\mathrm{p}<0.001)$ levels and AST $(p<0.001)$ activity was found to be statistically significant (Table 1). 
Table 1. The levels of certain biochemical parameters in infected and control group sheep

\begin{tabular}{|c|c|c|c|}
\hline Parameters & Group & Mean \pm SEM & P Values \\
\hline \multirow{2}{*}{$\mathrm{Na}(\mathrm{mmol} / \mathrm{L})$} & Infected & $153.05 \pm 0.69$ & \multirow{2}{*}{$* *$} \\
\hline & Control & $150.25 \pm 0.59$ & \\
\hline \multirow{2}{*}{$\mathrm{K}(\mathrm{mmol} / \mathrm{L})$} & Infected & $5.43 \pm 0.15$ & \multirow{2}{*}{ NS } \\
\hline & Control & $5.55 \pm 0.09$ & \\
\hline \multirow{2}{*}{$\mathrm{Cl}(\mathrm{mmol} / \mathrm{L})$} & Infected & $108.00 \pm 0.45$ & \multirow{2}{*}{ NS } \\
\hline & Control & $107.05 \pm 0.27$ & \\
\hline \multirow{2}{*}{$\mathrm{Ca}(\mathrm{mg} \backslash \mathrm{dL})$} & Infected & $9.88 \pm 0.08$ & \multirow{2}{*}{ NS } \\
\hline & Control & $9.72 \pm 0.10$ & \\
\hline \multirow{2}{*}{$\mathrm{Mg}(\mathrm{mg} \backslash \mathrm{dL})$} & Infected & $2.39 \pm 0.07$ & \multirow{2}{*}{ NS } \\
\hline & Control & $2.40 \pm 0.07$ & \\
\hline \multirow{2}{*}{ GGT (U\L) } & Infected & $60.25 \pm 3.11$ & \multirow{2}{*}{ NS } \\
\hline & Control & $58.70 \pm 1.93$ & \\
\hline \multirow{2}{*}{ ALT $(\mathrm{U} \backslash \mathrm{L})$} & Infected & $22.20 \pm 1.17$ & \multirow{2}{*}{ NS } \\
\hline & Control & $19.70 \pm 1.27$ & \\
\hline \multirow{2}{*}{ AST (U\L) } & Infected & $125.25 \pm 4.79$ & \multirow{2}{*}{$* * *$} \\
\hline & Control & $102.25 \pm 3.69$ & \\
\hline \multirow{2}{*}{ TBIL (mg \dL) } & Infected & $0.13 \pm 0.01$ & \multirow{2}{*}{$*$} \\
\hline & Control & $0.10 \pm 0.01$ & \\
\hline \multirow{2}{*}{$\mathrm{TP}(\mathrm{g} / \mathrm{dL})$} & Infected & $7.94 \pm 0.14$ & \multirow{2}{*}{$* * *$} \\
\hline & Control & $6.94 \pm 0.15$ & \\
\hline \multirow{2}{*}{$\mathrm{ALB}(\mathrm{g} \backslash \mathrm{dL})$} & Infected & $3.52 \pm 0.07$ & \multirow{2}{*}{ NS } \\
\hline & Control & $3.50 \pm 0.06$ & \\
\hline \multirow{2}{*}{$\mathrm{GLOB}(\mathrm{g} \backslash \mathrm{dL})$} & Infected & $4.42 \pm 0.17$ & \multirow{2}{*}{$* * *$} \\
\hline & Control & $3.44 \pm 0.17$ & \\
\hline \multirow{2}{*}{ TRIG (mg \dL) } & Infected & $17.05 \pm 1.07$ & \multirow{2}{*}{ NS } \\
\hline & Control & $18.35 \pm 1.17$ & \\
\hline \multirow{2}{*}{$\begin{array}{l}\text { CHOL } \\
(\mathrm{mg} \backslash \mathrm{dL})\end{array}$} & Infected & $59.50 \pm 2.38$ & \multirow{2}{*}{ NS } \\
\hline & Control & $57.70 \pm 2.55$ & \\
\hline
\end{tabular}

NS: non-significant $(p>0.05),{ }^{*}: p<0.05,{ }^{* *:} p<0.01,{ }^{* * *}$ : $\mathrm{p}<0.001$

Cystic echinococcosis is one of the significant parasitic zoonotic diseases that affect animals and humans alike (Demir and Mor, 2011). Besides the economic loss caused by the infection of the animals, the infection also represents a significant public health problem.

The disease is quite common in humans and animals in Turkey. Eastern, Southeastern, and Central Anatolia regions are the regions where the disease is most commonly encountered (Gicik et al., 2004; Karaman et al., 2005).

It has been reported that host biochemistry shows some alterations from normal physiology in animals with parasitic infections (Mert et al., 2003; Ayaz et al., 2006; Sahin and Akgul, 2006). Minerals have important roles in sustaining the normal physiological functions and protection of the organism against the disease. In studies conducted on parasite infested animals (Tanyuksel et al., 1995; Deger et al., 1997), changes in total serum protein levels, and the levels of certain vitamins, enzymes, and minerals were reported, while the parasitic diseases were reported to make infected animals susceptible to vitamin and mineral deficiencies.

A study conducted by Ayaz et al., (2006) found that there were some increases in some biochemical parameters including total protein, globulin, amylase, chlor, and vitamin B12 levels, and some decreases in albumin, magnesium, and phosphorus levels of sheep diagnosed with cyst hydatid (Ayaz et al., 2006).

In the physiopathology of the liver, AST, ALT, ALP, GGT, CPK, bilirubin and albumin, globulin protein tests are important parameters (Comba et al., 2017). Increased AST activity in the serum is a sensitive marker of liver damage (Meyer and Harvey, 1998). ALT activity in pigs, horses, goats, sheep and cattle is not specific for the liver for having a diagnostic significance (Kramer and Hoffman, 1997). Tennant (1997) reported that the activity of ALT in liver is low and that serum ALT is not remarkably elevated during infection with F. hepatica. The high activity of GGT is found in the liver, kidneys, pancreas, intestine and the spleen. Maden et al. (2003) reported that GGT is an important marker in lambs.

In a study conducted by Cinar et al. (2018) indicated that there were greater AST $(p<0.001)$ ALP $(p<0.05)$, and total bilirubin $(p<0.001)$ levels of sheep infected with the cyst compared to the control group. On the other hand, total protein $(\mathrm{p}<0.001)$ and $\mathrm{Mg}(\mathrm{p}<0.05)$ levels were found to be lower. In a study conducted by Sagkan-Ozturk et al. (2015) reported that the total protein and albumin levels of animals with cyst hydatids in lungs and livers were found to be significantly higher compared to the healthy animals. Heidarpour et al. (2012) have determined that the AST, GGT, and bilirubin levels of the camels infected with Cystic echinococcosis were higher compared to the control group.

In this study, the increases detected in the AST activities and total bilirubin levels of the sheep with Cystic echinococcosis (Heidarpour et al., 2012; Cinar et al., 2018), and the increase in the total protein (Ayaz et al., 2006; Sagkan-Ozturk et al., 2015) and globulin levels (Ayaz et al., 2006) are consistent with the results of the aforementioned studies. Yuksek et al. (2007) report that the ALP and AST activities of sheep infected with endoparasites are higher compared to healthy animals and that the increase is caused by the necrosis or cholestasis of the hepatic cells. It is believed that the increase in AST activity and bilirubin levels might be due to necrosis and/or cholestasis of the hepatocytes, while the increase in total protein and globulin levels might be attributed to the deterioration of the protein metabolism.

\section{CONCLUSION}

The results of the study indicate that the determination of the changes in AST, total protein, globulin and total bilirubin levels of the animals 
infected with cystic echinococcosis could be used as assistive laboratory analyzes to determine the physiopathological changes in their livers and the prognosis of the diseased animals.

\section{REFERENCES}

Ayaz E, Ertekin A, Ozdal N, Tas Z 2006. Some Biochemical Parameters in Sheep Infected with Endoparasites (Fasciola spp., Dicrocoelium dendriticum, Hydatid cysts, Trichostrongylidae and Protostrongylidae). Turkiye Parazitol Derg, 30 (4): 57-61.

Cinar M, Aydenizoz M, Gokpinar S, Camkerten G 2018. Evaluation of biochemical parameters and oxidative stress in sheep naturally infected with Dicrocoelium dendriticum and hydatid cysts. Turkish Journal of Veterinary and Animal Sciences, 42 (5): 423-428.

Deger Y, Gul A, Bildik A, Dede S, Yur F, Deger S 1997. Parazitli köpeklerin bazı kan parametreleri ile plazma vitamin $\mathrm{C}$ düzeylerinde görülen değişiklikler. Türkiye Parazitol Derg, 21: 195-198.

Demir P, Mor N 2011. Seasonal Distribution and Economic Importance of Cystic Echinococcosis in Cattle Slaughtered at Kars Municipal Abattoir, Turkey. Turkiye Parazitol Derg, 35: 185-188.

Ersayit D, Kilic E, Yazar S, Artı T 2009. Oxidative Stres in Patients with Cystic Echinococcosis: Relationship between Oxidant and Antioxidant Parameters. Erciyes University J Health Sci, 18: 159-166.

Gicik Y, Arslan MO, Kara M, Kose M 2004. The Prevalence of Cystic Echinococcosis in Cattle and Sheep Slaughtered in the Kars Province. Turkiye Parazitol Derg, 28 (3): 136-139.

Gokcen A, Sahin T, Camkerten I 2006. A primary case of Cardiac cyst hydatid in a calf, in Turkey. Yüzüncü Yıl Üniversitesi Veteriner Fakültesi Dergisi, 17 (1): 33-35.

Hakverdi S, Culha G, Canda MS, Yaldiz M, Altintas S 2008. Problem Of Cystic Echinococcoss in Hatay. Turkiye Parazitol Derg, 32: 340-342.

Hanedan B, Kirbas A, Kandemir FM, Ozkaraca M 2015. Arginase activity and total oxidant/antioxidant capacity in cows with lung cystic echinococcosis. Med Weter, 71 (3): 167-170.

Heidarpour M, Mohri M, Borji H, Moghdass E 2012. Oxidative stress and trace elements in camel (Camelus dromedarius) with liver cystic echinococcosis. Veterinary parasitology, 187 (3-4): 459-463.

Heidarpour M, Mohri M, Borji H, Moghdass E 2013. Oxidant/antioxidant status in cattle with liver cystic echinococcosis. Vet Parasitol, 195:(1-2) 131135.

Irak K, Celik BA, Karakoc Z, Celik OY, Mert H, Mert N, Kaya MO (2018). Oxidant/Antioxidant Status, PON1 and ARES Activities, Trace Element Levels, and Histological Alterations in Sheep with Cystic Echinococcosis. Iranian Journal of Parasitology, 13(3): 448-456.

Kam K 2016. Investigation of mineral content of the serum and cyst fluid in sheep with hydatid cysts. (Master thesis), Yuzuncu Yll University, Institute of Health Sciences Department of Biochemistry, Van, Turkey.

Karagul H, Altıntaş A, Fidancı UR, Sel T 2000. Klinik Biyokimya. 1st ed. Ankara, Turkey: Medisan Yayınevi.

Karaman U, Miman O, Kara M, Gicik Y, Aycan OM, Atambay M 2005. Hydatid Cyst Prevalence in the Region of Kars. Türkiye Parazitol Derg, 29 (4): 238240.

Kilic E, Yazar S, Bakol G, Artı T 2010. Antioxidant and nitric oxide status in patients diagnosed with Echinococcus granulosus. Afr J Microbiol Res, 4 (22): 2439-2443.

Koltas IS, Yucebilgic G, Bilgin R, Parsak CK, Sakman G 2006. Serum malondialdehyde level in patients with cystic echinococcosis. Saudi Med J, 27 (11): 1703-1705.

Maden M, Altunok V, Birdane FM, Aslan V, Nizamlioglu M 2003. Blood and colostrum/milk serum Y-glutamyltransferase activity as a predictor of passive transfer status in lambs. Journal of Veterinary Medicine Series B, 50(3): 128-131.

Mert N, Kozat S, Ekin S, Gunduz H, Denizhan V 2003. Doğal kronik Fasciolasisli koyunlarda serum sialik asit ve serum lipid-bağlı sialik asit düzeyleri. 13 . Ulusal Parazitoloji Kongresi, 8-12 Eylül 2003, Konya, Turkey.

Meteorology 2018. Turkish State Meteorological Service. Thornthwaite climate classification. (19382017). Retrieved from https://goo.gl/ud7dBK. (Access Date:10.10.2018).

Sagkan-Ozturk A, Durgut R, Ozturk O 2015. Oxidant/antioxidant status in lambs and sheep with liver and lung cystic echinococcosis diagnosed by ultrasonography and necropsy. Veterinary parasitology, 208 (3-4): 280-285.

Sahin T, Akgul Y 2006. Investigation of Some Trace Element Levels and Biochemical Parameters in Sheep with Endoparasite. YYÜ Sağlık Bilimleri Dergisi, 9 (1): 100-106.

Tanritanir P, Özdal N, Ragbetli C, Yörük I, Ceylan E, Deger S 2009. Some biochemical parameters and vitamins levels in the hair goats naturally mixinfested with endo-ectoparasites (lice (linognathus africanus) and Trichostrogylidae sp.). J Anim Vet Adv, 9: 1707-1711.

Tanyuksel M, Sayal A, Aydin A 1995. Paraziter hastalıklarda eser element düzeyleri. Türkiye Parazitol Derg, 19: 315-321.

Tennant BC, Center SA 2008. Chapter 13: hepatic function. In Clin-ical Biochemistry of Domestic Animals. sixth ed. In: Kaneko, J.J.,Harvey, J.W., 
Bruss, M.L. (Eds.), Academic Press, New York, USA, pp. 379-412.

Uslu U, Akalin PP, Şahin EY, Altunok V 2011. Some biochemical parameters in yearling sheep naturally infected with Coenurus Cerebralis. Fresenius Environmental Bulletin, 20(2): 411-414.

Vengust G, Klinkon M, Bidovee A, Vengust A 2003. Fasciola hepatica: effect on blood constituents and liver minerals in fallow deer (Dama dama). Vet Parasitol, 112: 51-61

Yarim GF, Umur S, Acici M, Beyhan YE 2010. Serum sialic acid levels in cattles with cystic echinococcosis. Ankara Üniv Vet Fak Derg, 57: 6163.

Yildiz K, Gurcan S 2003. Prevalence of hydatidosis and fertility of hydatid cysts in sheep in Kirikkale, Turkey. Acta Veterinaria Hungarica, 51 (2): 181187.

Yuksek N, Altug N, Gul A 2007. Therapeutic effect of the combination of trichlobendazole and levamisole in sheep with endoparasite infection. YYU Vet Fak Derg, 18: 19-24.

Comba B, Mert H, Comba A, Mis L, Mert N 2017. The Some Hematological and Biochemical Parameters In Karakul and Norduz Sheep.Van Vet J, 28 (3): 137-140.

Meyer DJ, Harvey JW 1998. Veterinary Laboratory Medicine. Interpretation and Diagnosis. 2nd ed., W. B. Saunders Company. Philadelphia, London, Toronto, Montreal, Sydney, Tokyo. pp. 157-187.

Kramer Jw, Hoffman We 1997. Clinical Enzymology. In: Clinical Biochemistry of Domestic Animals. (Kaneko, J. J., J. W. Harvey, M. L. Bruss, Eds.). Academic Press. San Diego,London, Boston, New York, Sydney, Tokyo, Toronto. pp. 303-325.

Tennant BC 1997. Hepatic Function. In: Clinical Biochemistry of Domestic Animals. (Kaneko, J. J., J. W. Harvey, M. L. Bruss, Eds.) 5th ed., Academic Press. San Diego, London,Boston, New York, Sydney, Tokyo, Toronto. pp. 327-352. 